\title{
The Influence of Globalization Processes on Transformation of Financial Mediation
}

\author{
Tkachenko Nataliia, Vyhovska Valentyna, Boldova Antonina
}

\begin{abstract}
The theoretical analysis and conceptual approaches to the clarification of the definition of "globalization" have been formulated, and the meaningful interpretation of the concepts of "globalization", "internationalization" and "international economic integration" has been presented. The main directions of globalization processes and their influence on the development of financial mediation have been investigated.
\end{abstract}

Keywords: globalization, integration, internationalization, international economic integration, globalization of international financial operations, financial intermediation.

\section{INTRODUCTION}

The all-embracing phenomenon of the modern world economy is global. Modern researchers have a fairly broad information base on various aspects of globalization. At the same time, many other issues of both the development of globalization and its impact on certain processes, in particular economic ones, remain unresolved for research scientists. There is currently no consensus on this issue: whether globalization is a one-way process or it involves alternative ways of development; will globalization lead to a homogeneous integrity or it consists of different components of development? What effect does globalization have on the functioning of the national financial intermediation system and on individual financial intermediaries?

Researches devoted to the peculiarities of globalization and its impact on the socio-economic development of the countries have been carried out by such domestic and foreign scholars as A. Bobrovnikov, R. Voitovych, A. Halchinskyi, I. Hretikova, V. Davydov, O. Diyubliuk, V. Zolotarev, V. Inozemtsev, M. Castells, V. Koziuk, D. Lebedev, T. Levitt, J. McLean, I. Osadcha, R. Robertson, O. Rohach, J. Soros, A. Filippchenko, A. Holopov, A. Chumakov and many others. However, further and in-depth study of these issues and the development of the peculiarities of the transformation of certain spheres of economic and financial activity remains under the influence of globalization processes.

Revised Manuscript Received on November 15, 2019

* Correspondence Author

Tkachenko Nataliia, Doctor of Economic Sciences, Professor, Kyiv National Taras Shevchenko University,Kyiv, Ukraine;

e-mail: tkachenko_nt@ukr.net ORCID ID 0000-0001-6312-4586

Vyhovska Valentyna, Doctor of Economic Sciences, Professor, Chernihiv National University of Technology, Chernihiv, Ukraine

E-mail: vv.vygovska@gmail.com, Tel:+380504651545 ORCID ID 0000-0001-8632-9656, Resecher ID D-5034-2015

Boldova Antonina, $\mathrm{PhD}$ in pedagogy, Associate Professor of the Department of Financial market, Deputy Director of the educational activities Institute of Finance, Banking, University of State Fiscal Service of Ukraine ORCID ID: 0000-0001-5116-963X

boldova_antonina@ukr.net

\section{MATERIALS AND METHODS}

Definition of conceptual approaches to the clarification of the meaning of globalization and the phasing of its origin; the distinction between meaningful content and the distinction between the concepts of "globalization", "internationalization" and "international economic integration"; the analysis of the main trends of globalization processes and its impact on the development of the financial intermediation.

\section{RESULTS}

If we study the definition of "globalization" in terms of its origin, it comes from the concept of "global" (from the Latin. Globus - bullet from French. Global - a comprehensive, overall), and the terms "Global", "globalism" and "globalization ", Which became especially popular in the 90s of the XX century, are synonymous with such philosophical terms as" one "," general "and" all-round ". A little later, the term "globalization" becomes more habitual and commonly used.

It should be noted that there are no clear approaches to finding out the period of the emergence of globalization. Some researchers study the development of globalization with the history of the emergence of money and argue that the history of globalization has the same historical period as money have. There are 8 stages of globalization, each of which is associated with different interests [1, c. 10]:

- the first stage (VI-XV centuries) is the period of the union of the economies of the south and north of Europe;

- the second stage (1501-1557 years) is a period of great geographical discoveries;

- the third stage (1557-1618 biennium) is the time, called the "Century of the Genoese";

- the fourth stage (1648-1701) is the years of global influence of the Dutch capital and French politics;

- the fifth stage (1700-1795) is a period associated with inflation and economic degradation in France;

- the sixth stage (1795-1914) is a period of intense industrial and economic growth of England and Europe. In the framework of this stage, the liberalization of the world economy was dominated by British exports;

- the seventh stage (1914-1945) is the period of the World War I, when all the warring countries became debtors of the United States. We also have to add a pan-European crisis, inflation and depression of the 1930s. The consequence of this stage is World War II; 
- The eighth stage began after the World War II.

Another point of view is presented by A.H. Rumiantsev [2], which distinguishes 4 stages on the basis of the division of human activities:

-the first stage refers to the period of "Overseas Trade", the emergence of which is associated with the beginning of the Great Geographic Discoveries;

-the second stage is "Factory Production";

-the third stage is the "Colonial division";

-the fourth stage is characterized by the era of the 'Information Dimension of Humanity.

A.N. Chumakov [3], in his turn, also distinguishes 4 stages, but uses the time approach:

- $\quad$ the first stage falls on prehistoric times;

- $\quad$ the second stage is characterized by the beginning of history associated with the implementation of the Neolithic revolution;

- $\quad$ the third stage was named by K. Jaspers At this stage, the first signs of globalization appear;

the fourth stage is the era of Great Geographical Discoveries, associated with the beginning of a real globalization that began in the early twentieth century. fundamental, but with the release of man in space and the development of information revolution - a multidimensional one.

IMF experts to globalization dedicated more than a hundred years, assuming that they are widely evident in the era of the gold standard, ie the period from 70s of the XIX century to the World War I [4, c. 18].

In our opinion, a more legitimate point of view, according to which globalization is a process that first appeared in the 90 years of XX century. and has no analogues in history. It was then that such processes as a revolution in the information and communication sphere; increasing homogeneity of the "landscape" of the world economy, which is associated with the collapse of the socialist system; liberalization of economic space; accumulation, concentration of capital and increase of significance of transnational corporations, etc. started.

According to J. Soros, after World War II, the economies of the countries were inherent in a purely national character, as a result the majority of currencies were nonconverted. It was only in the 1970's when global financial markets appeared. Along with this the control over the movement of capital gradually slows down, so in Great Britain the lift was officially banned only in 1979. Only in the early 1990's, with the collapse of the Soviet empire, world markets become truly global [5, c.16].It should be noted that, in addition to deregulation measures, the elimination of obstacles to the flow of capital between markets and countries has contributed to the widespread introduction of modern information technologies, in particular telecommunications and the Internet.

It is worth noting that the term "globalization" was first used by J. McLean in 1981 in related social sciences. In particular, he stressed " on understanding and explanation of the historical process of strengthening the globalization of social relations" [6]. We have to consider that J. McLean uses the word "globalization," giving it the value of the property of relations between people, meaning the large-scale content of this phenomenon [7].
The derivation of the term is related to the name of the Anglo-American sociologist R. Robertson, who in 1983 applied the concept of "globality" in one of his scientific works, and in 1985 provided a meaningful load of the term "globalization". In 1992, he outlined the foundations of his concept in a book devoted to the study of the development of society and culture, in which he emphasized the dynamic change in human consciousness over the past few centuries. In this context, the opinion of R. Robertson in relation to the fact that globalization is associated with "compression of the world in the human consciousness and increased awareness of the world as a whole"is interesting. [8, c. 45].

In the modern understanding, the term "globalization" appeared a little later. It wass introduced into the scientific vocabulary of T. Levitt in 1983 to describe the phenomenon of the merger of markets for individual products produced by transnational corporations, [9].

According to the analisys of the Russian researcher I.H. Hretikova [10] primacy, based on extensive advances in global issues and widespread publicity, belong to the Rome Club (an international organization bringing together entrepreneurs, executives, politicians, trusted experts, scholars from different countries, began its activities in 1968). Representatives of the Rome Club were A. Peccsi, E. Pestel, M. Mesarovych, J. Tinberhen, E. Mann-Borghese, J. Forrester, A. King, B. Schneider, etc.).

It should be noted that globalization has become one of the most not only popular but also necessary concepts in various fields of scientific knowledge in recent years, but the unified conceptual basis for the views on understanding the of the impact on different spheres of activity has not still steel been formed.

What is globalization and how does it relate to the concepts of "integration" and "internationalization"? Thus, today there are no uniform approaches to understanding the essence of this economic phenomenon, and the definition of the definition of "globalization" is characterized by a wide variety.

Globalization as a concept is often used both in scientific and in political literature. According to V.L. Inizemtsev "period of the development of the concept of globalization fell to the first half of the 1990's, three different trends contributed to it. First, the economic power of the Western world was growing.. Secondly, the general euphoria was caused by the active expansion of Western values by the countries of the former communist camp. Third, the development of communications and information exchange created the impression of the reverse effect of the cultures of peripheral states on postindustrial countries "[11, c. 28].

According to Professor A.A. Filipchenko, globalization "manifests itself in the growth of international trade and investment, unprecedented in this diversification of the workforce, a significant increase in the role of TNCs in global economic processes, the exacerbation of global competition, the emergence of systems of global strategic management" [12, c. 45]. In turn, A.N. Chumakov, describing globalization, notes that it "acts as both a fact and a phenomenon when it is perceived as an objective reality that claims to be a closed world of space, a single world economy, a general ecological interdependence, global communications, etc., and 
which in this degree can not be ignored by anyone "[13].

According to R.V. Voitovych [14], globalization in its contemporary dimension creates the basis for "reformatting" the structuring of the modern world, and as a consequence, leads to the correction of national systems of state administration, the reconsideration of strategies of economic, political and spiritual development, which creates the basis for the functioning of the world on the basis of interdependence.

\section{DISCUSSION}

Given the wide variety of views on globalization, we substantiate existing conceptual approaches.

1. Globalization represents a new phenomenon for the world economy, which fundamentally changed the world. The representative of this concept was K.Ome.

2. Globalization is not something phenomenal; in the scale of the world economy there is a redistribution of power and influence of countries, as well as companies and banks. The supporter of such a concept is M. Castells [15]. In the work of O.I. Rohach states that globalization means "the growth of global integration, especially through trade and financial flows" [16, c. 38]. According to A.V. Holopov, globalization can be characterized as "strengthening the interdependence of national economies, the interaction and interplay of various spheres and processes in the world economy" [17, c. 15].

3. Globalization is seen as an objective historical process, as a qualitatively new stage in the internationalization of the economical, political and cultural life of society. According to I. Osadchyi, globalization is " the next stage of internationalization, based on the development of information technology" [18, c. 3].

4. Globalization is seen as a process of global integration. The Ukrainian scientist O. Dziubliuk in the meaning of the term "globalization" includes "the process of increasing the integration of national economies into a single global market for goods, services, capital and labor" [19, c.8]. At the same time, he emphasizes that the main direction of this process is the globalization of the financial sector of the economy.

5. Globalization represents the "americanization" and the expanded westernization of the world, as well as the spread of western capitalism and Western institutions. D.Lebedev, clearly states that "... globalization appears as" Americanization "and" Westernization "of the world" [20, c.461].

In our opinion, the terms "amerization" and "westernization" in terms of globalization can be used as synonyms, since both characterize the process of assimilating many values, either Western or American, and the style of their lives and behaviors.

Often, the globalization of the world economy is used as a synonym for the internationalization of economic life.At the same time, it is appropriate to emphasize that the latter implies an increase in the interaction and interconnection between countries in the historical aspect, and globalization is a characteristic of the internationalization of economic life, when it has practically covered the whole world

We believe that globalization is fundamentally different from the internationalization of the formation of interstate entities, laying the foundations for a new, global community. In view of this, we agree with V. Kozyuk [21, c.7], which states that globalization can not be considered the next stage in the development of the internationalization of the world economy, because it is a qualitatively different phenomenon that demonstrates a new, integrative status of the functioning of the international and national economies, the signs of which should include a tendency towards the formation of the integrity of the world based on the integration of markets.

Concerning the concept of "integration", among scholars-economists, there are also different points of view on its essence. Thus, some researchers define economic integration as a process of eliminating economic boundaries between two or more economies, but it is not necessary to eliminate territorial and / or political boundaries between states. Others understand the process of integration as the creation of several countries of a single market space on the basis of spontaneous market forces and free competition.

At the same time, the analysis of literary sources makes it possible to formulate a conclusion on the allocation of general characteristics of integration, which are the unification of countries and the creation of new geopolitical units; unification and synchronization of policies on various issues; increasing the interdependence and interdependence of the economies of the countries that are part of the association. The main features of international economic integration include:

-cooperation between national economies of different countries and their full or partial unification, elimination of barriers to the movement of goods, services, capital, labor between countries;

- convergence of markets of individual countries in order to create a single market;

-elimination of differences between economic entities, which are related to different states;

- the absence of any discrimination between foreign partners in each of the national economies.

The essential presentation of the concepts of "globalization", "internationalization" and "international economic integration" is shown in Figure 1.

Therefore, it is legitimate to recognize that international economic integration is characterized by deepening of the international division of labor, the internationalization of capital, the development of scientific and technological progress, and an increase in the degree of openness of national economies. It is clear that globalization and integration have largely contributed to the development and deepening of economic relations between countries that differ in terms of economic development, the structure of economies, the growth of world trade, the acceleration of the circulation of financial flows, the development of world financial markets, transnational corporations, etc.

The economics literature covers the diametrically opposed views of scientists on the effects of globalization. Some see globalization as a serious threat to the world economy, others see it as a means to further economic progress. There are also somewhat different views of scholars on the duality of the processes of globalization, which, on the one hand, ensure the formation of conditions facilitating entry into global economic relations and accelerating economic development, and on the other hand, globalized countries may be discriminated against by the globalizing powers, receive one-sided development separate

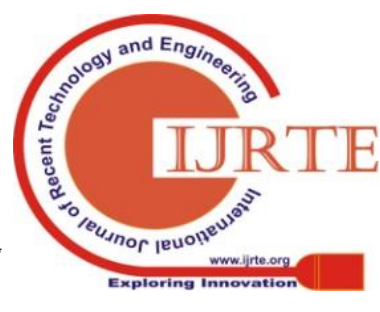


branches. Positive effects of globalization processes can be called:

-promoting the deepening of specialization and the international division of labor, which leads to a more efficient allocation of resources and, as a consequence, increases the living standards of the population;

- mobilizing by countries significant volumes of financial resources and encouraging free trade on a mutually beneficial basis;

-stimulation of the further development of new technologies and intensification of their dissemination;

-grows of international competition;

- increase of labor productivity as a result of rationalization of production at the global level and dissemination of advanced technologies, as well as competitive pressure in favor of the continuous introduction of innovations on a global scale, etc.

In addition to the benefits, globalization brings both challenges and dangers into the modern world. What negative is globalization still? Among the potential negative consequences of globalization, first of all, the ruin and the exit on the world's "edge of development" of certain national economic systems due to fierce competition may be possible. This means that in the globalized countries, the social production of material goods takes place against the background of the risks of globalization, when socioeconomic problems associated with income distribution and employment are emerging. The negative effects of globalization can also be attributed to: the environmental crisis as a result of the broad industrial activity of transnational corporations, whose main task is to increase profits; possible deindustrialization of national economies; the possibility of shifting control over the economies of individual countries to others, first of all to stronger states, transnational corporations or international organizations; the risk of destabilization of the financial sector; internationalization of crime, etc.

But, despite the individual negative effects of globalization, one should be aware that globalization is an irreversible and objective process. Globalization covers all regions and sectors of the world economy. This changes the relationship between external and internal factors of development of national economies: yet external factors become the priority. As a result, no state can effectively formulate and implement a strategy for its development, without taking into account the priorities and norms of behavior of the main participants to world economic activity.

Modern globalization of the world economy is manifested in such processes (Fig. 2).

\section{Conclusion}

So, it should be noted that globalization:

1) on the one hand, this is an irreversible and necessary process of development, and on the other hand, it is the sphere of establishing certain relations and confronting the various forces and interests that take place in the modern world;

2) characterizes the development of internationalization in terms of expansion of its economic field and the differentiation of forms of economic bonds, and integration the highest degree of development of its depth, in view of the formation of new qualitative properties and regularities of international economic systems;
3 ) is an objective process that has a systemic character and covers all spheres of life of society . Being multi-faceted and diverse, globalization processes are primarily manifested in the economic plane, forming a qualitatively new stage in the internationalization of economic life and influencing the functioning of economic systems;

4) as the new state of the world economy is the formation of a unified informational and economic space for the unhindered movement of transnational financial capital in the world economy;

5 ) is an integral feature of today's and tomorrow's world. Globalization can not be stopped, it can not be managed, and its consequence is a growing degree of involvement in the global economy and the integration of financial markets.

In addition, globalization is a consequence of the evolution of processes of internationalization of economic life, its qualitatively different stage, which has all the features of internationalization of the economy, and a completely new form, for example, the formation of economic institutions. Of course, we can not ignore the hypothesis of the well-known English sociologist R. Robertson, which we fully support, that the global can not be opposed to the local, but universal - to a partial one. So, local is an aspect of globalization, while global creates a localized one. Traditional activities that are characteristic of local communities disappear, other activities that are far from these local contexts come into their place. Therefore, R. Robertson proposes to replace the term "globalization" with the term "glocalization" for greater precision. The latter is composed of two words globalization and localization - to emphasize their mutual existence at present.

In our opinion, globalization is a kind of metaphor, which indicates that the global does not exclude local, and vice versa. There are many ways to practice globalization, which includes combinations of local and global. Has not passed the process of globalization and the financial sphere. In the 1990s, the World Bank recognized the parallel existence of localization and globalization trends and stimulated research that revealed the essence of governance in the emerging globalized spaces. At the same time, the gradual growth of economic openness changes the ratio of external and internal factors of development of national economies. At present, the economic situation beyond national boundaries has an increasing impact on national economies. This means that national states in today's conditions can no longer regulate economic life inside the country, regardless of the processes taking place in the world economy.

\section{REFERENCES}

1. Zolotarev V. Globalization as an irreversible development process / V.Zolotarev, N. Nevskaya, T. Komarova // Bulletin of the Rostov State Economic University "RINCH". - 2007. - No. 1 (23). - P. 9-13.

2. Modern state and challenges of post-industrial society. [Electronic resource]. - Access mode: http://www.law.net.ru/stat_is/1v.htm.

3. Chumakov AN Globalization: contours of the holistic world. - M .: Prospect, 2005. [Electronic resource] - Access mode: http://www.globalistika.ru/p_r9.htm.

4. Davydov V. The phenomenon of financial globalization. Universal processes and reaction of the Latin American countries - M., 2000. 204 p.

5. Soros G. On Globalization / Translate A. Bashkishov - M .: Eksmo, 2004. - 244 p. 
6. McLean D. In search of a new paradigm of globalization: East-West, teaching democracy // Comparative Philosophy. Knowledge and faith in the context of the dialogue of cultures. - M., 2008. - P.268-277.

7. Scholte J. A. Beyond the Buzzworld: Towards a Critical Theory of Globalization. Kofman E., Youngs S. (eds): London. - 1998 - P. 290-352.

8. Robertson R. Interpreting Globality [text] / Robertson R. World Realities and International Studies. Glenside (Pa.), 1983. - P. 45.

9. Levitt Th. Globalization of Markets // Harvard Business Review. 1983. Vol. 61. May-June.

10. Gretikova I. Theoretical Aspects of Globalization // Bulletin of the OGU. - 2008.-8 (90). - P. 4-9.

11. Inozemtsev V. Globalization: Illusion and Reality // Free Thought XXI. - 2000. - No. 1. - P. 28.

12. Ukraine and the world economy: interaction at the turn of the millennium: A manual / A. Filippchenko, V. Budkin, A. Galchinsky and others. - K.: Lybid, 2002. - 470 pp.

13. Chumakov A. Globalization: contours of the holistic world. - M : Prospect, 2005. [Electronic resource] - Access mode: http://www.globalistika.ru/p_r9.htm.

14. Voitovich R. Impact of globalization on the development of the modern world / R. Voitovich [Electronic resource] - Access mode: http://www.vidkryti-ochi.org.ua.

15. Castells M. The Power of Identity. Oxford, Blackwells, 1997.

16. International finance: Textbook / Ed. O. Rogach. - K.: Lybid, 2003. $784 \mathrm{p}$

17. Kholopov A., Globalization and macroeconomic equilibrium / A Hkolopov // World Economy and International Relations. - 2005. №2. - P. 15-23.

18. Osadchaya I. Globalization and the state: a new economy in the regulation of the economy of developed countries / I. Osadchaya //

\begin{tabular}{|c|c|c|}
\hline Globalization & $\begin{array}{l}\text { Internationali } \\
\text { zation }\end{array}$ & $\begin{array}{c}\text { International Economic } \\
\text { Integration }\end{array}$ \\
\hline $\begin{array}{l}\text { the spatial characteristic of the } \\
\text { internationalization of the } \\
\text { economy, when the global market } \\
\text { is global and embracing all world } \\
\text { economic relations and the entire } \\
\text { world economic space, in } \\
\text { connection with which the } \\
\text { growing attention to exogenous } \\
\text { factors of economic development }\end{array}$ & $\begin{array}{l}\text { the historic al } \\
\text { trend of } \\
\text { growing } \\
\text { interaction } \\
\text { between } \\
\text { regions, } \\
\text { countries, and } \\
\text { national } \\
\text { economic } \\
\text { complexes }\end{array}$ & $\begin{array}{l}\text { the highest degree and form of } \\
\text { internationalization of economic } \\
\text { life, which involves the economic } \\
\text { interconnection of two or more } \\
\text { countries and converts into the } \\
\text { merger of national markets of } \\
\text { goods, services, capital and labor, } \\
\text { resulting in the formation of large } \\
\text { international } \\
\text { complexes }\end{array}$ \\
\hline
\end{tabular}

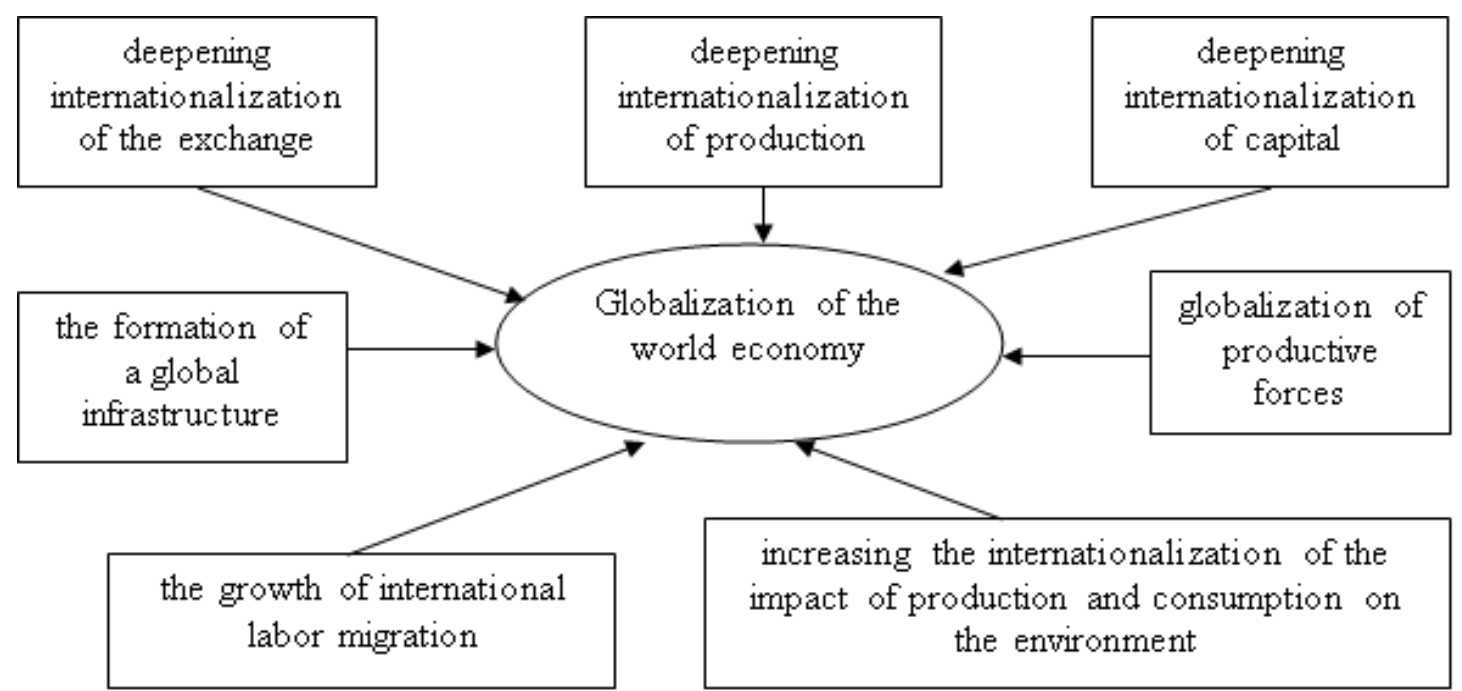

World Economy and International Relations. - 2002 - No. 11. - P.

. Dzubluk O. The monetary and credit system of Ukraine in the context of globalization processes / O. Dzubluk // Bulletin of the TANG. 2006. - №2. - P. 7-20. Economic System in the Conditions of Globalization / D. Lebedev // Safety of Eurasia. - 2003. - №2. - P. 461-476.

21. Kozyuk V. Monetary policy in global conditions. - Ternopil: View

\section{AUTHORS PROFILE}

Tkachenko Nataliia , Doctor of Economic Sciences, Professor, Kyiv ional Taras Shevchenko University,Kyiv, Ukraine;

e-mail: tkachenko_nt@ukr.net

Vyhovska Valentyna, Doctor of Economic Sciences, Professor, Chernihiv National University of Technology, Chernihiv, Ukraine

ORCID ID 0000-0001-8632-9656, Resecher ID D-5034-2015

Department of Financial market, Deputy Director of the educational activities Institute of Finance, Banking, University of State Fiscal Service of raine

ORCID ID: 0000-0001-5116-963X

boldova_antonina@ukr.net 
The Influence of Globalization Processes on Transformation of Financial Mediation

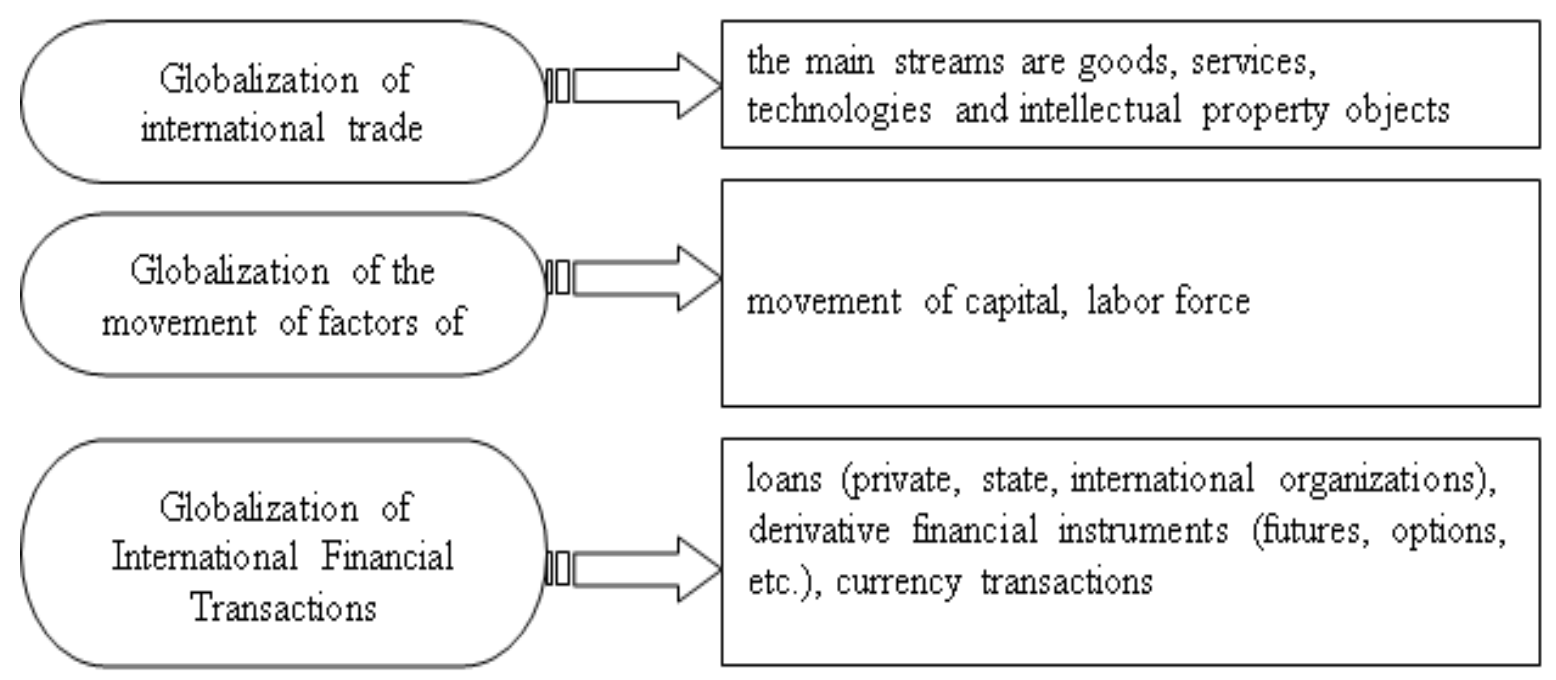

Fig. 1. The concepts of "globalization", "internationalization" and "international economic integration"

Fig. 2. Modern globalization of the world economy is manifested in such processes 